Original Article

\title{
Intern's experience throughout their graduating years - a cross sectional questionnaire survey
}

\section{The Xing Hui ${ }^{1}$, Suraya Sajoli ${ }^{1}$, Ravi V. Shirahatti ${ }^{2}$, Audrey M D'Cruz ${ }^{2}$}

${ }^{1}$ Interns, ${ }^{2}$ Readers, Department of Public Health Dentistry, A.B. Shetty Memorial Institute of Dental Sciences, Nitte University, Mangalore, Karnataka, India.

Correspondence : Teh Xing Hui, Intern, A.B. Shetty M emorial Institute of Dental Sciences, Nitte University, Deralakatte, M angalore - 575 018, Karnataka, India. E-mail : emmateh_91@yahoo.com

Received

: 10.03 .2015

Review Completed : 10.08.2017

Accepted

: 12.08 .2017

Keywords : Dental education; Dental graduate student; Internship; graduating questionnaire; Educational experience.

\begin{tabular}{|c|}
\hline Access this article online \\
\hline Quick Response Code \\
\hline
\end{tabular}

\begin{abstract}
Introduction: This survey was conducted amongst undergraduate students upon completing internship. The objective of the study was to assess the students' perceptions about their learning experiences in the dental college and their future career plan in dentistry.
\end{abstract}

M aterials and methods: $A$ descriptive, cross-sectional study was conducted on 81 interns of the dental college by distributing structured survey questionnaire. The components of the survey include; undergraduate curriculum, student motivation and support, infrastructure and facilities, components of teaching-learning programs, administrative services, confidence level in carrying out clinical proceduresand postgraduate specialty preference.

Results: M ajority of the interns ( $n=73,90.12 \%$ ) responded to the survey handouts. M ajority of the interns ( $n=61,83.5 \%$ ) agreed that they are satisfied with the overall BDS training and about $86.3 \%$ wanted to pursue further postgraduate study.

Conclusion: The undergraduate curriculum was satisfactory to the majority of the respondents; there are still certain aspects of the curriculum that need to be improved in their perception.

\section{Introduction}

Education is a dynamic process that is constantly evolving over a period of time. It is important that the curriculum be tailored befitting the student's mindset and also according to the emerging needs of the society. Hence, one of the best ways to evaluate the current curriculum is by looking from the students' perspective as they are the receivers, the 'beneficiary' of the entire program and the 'fruits of the planted seeds'. At present, BDS program in India consists of a total of 5 years, out of which, 4 years of academic training and 1 year of internship ${ }^{1}$. The academic training involves theory classes and clinical sessions. There are a number of studies in Europe, Malaysia, and other countries that have used Dundee Ready Education Environment Measure (DREEM ) inventory that measures students' opinion after their graduation in an exit survey ${ }^{2-7}$. There are very few studies done in India that obtain student perceptions about the curriculum ${ }^{8}$. Therefore, a study was done amongst interns of A.B.Shetty M emorial Institute of Dental Sciences, Mangalore (subsequently referred to as ABSM IDS) who were in the frag end of their internship and were graduating in the subsequent week in August 2014.

The questionnaire study was planned to gain student's feedback regarding the current curriculum at our dental institution and specific feedback about several components of the curriculum that include; undergraduate curriculum, student motivation and support, infrastructure and facilities, components of teaching-learning programs, administrative services, confidence level in carrying out clinical procedures and postgraduate specialty preference. The purpose of this study was to evaluate the current curriculum of the college from students' perspective in order to achieve effective and efficient education delivery. 


\section{Materials and Methods}

A cross-sectional study was employed encompassing all the interns of A. B. Shetty Memorial Institute of Dental Sciences, Mangalore nearing completion of their B.D.S (Bachelor of Dental Surgery) in August 2014. Ethical clearance was obtained from the institutional ethics committee before commencement of the study. All the interns $(n=81)$ were approached to participate in the survey out of which 73 interns (90.12\%) responded by agreeing to provide an informed consent and taking time to respond to the survey.

The questionnaire used was already developed and used by one of the authors ${ }^{8}$. Relevant studies relating to graduating students like the study from Association of American Medical College's 2000 graduation questionnaire $^{9}$ and the Dundee Ready Environment (DREEM) inventory ${ }^{10.11}$ were referred while development of the aforementioned questionnaire. The same questionnaire was used in the present study with minor modification by adding components related to rural satellite center postings. The domains that were studied included intern's opinions on the undergraduate curriculum, student motivation and support, institutional infrastructure and facilities, components of teachinglearning programs, administrative services, confidence level in carrying out clinical procedures and postgraduate specialty preference. Open ended questions were asked regarding the interns' experiences in the rural satellite centers.

A questionnaire form consisting of 53 questions were outlined and finalized by the investigators. Then, the interns were invited to participate and were given the questionnaire once they consented in writing to participate in the survey. The questionnaire was provided in printed form to all the respondents and they were requested to complete the responses and return the questionnaire in about 30-45 minutes. All the questionnaires were self-completed and anonymous and the students returned it immediately upon completion. The responses were coded and entered in Microsoft Excel
2007. The data entry was verified for accuracy of the entries by re-checking three questions from every third questionnaire. Once the verification was completed, the data was copied to SPSS statistical package and percentages and frequencies were calculated for the data. The open-ended questions in the questionnaire were assembled using qualitative research methods of data processing and have been presented under the fields that developed after the qualitative analysis ${ }^{12}$.

\section{Results}

The results displayed overall positive responses in learning experience in the undergraduate curriculum (Table 1). About $91.8 \%$ of the respondents stated that internship is a necessary part of the BDS curriculum for consolidating learning; $87.7 \%$ of the respondents stated that they have received adequate basic sciences training that prepared them for clinical practice. However, a minority of the participants commented that they were less satisfied with the training. The interns suggested that classes could be more organized so that there is less repetition of same topics and timely completion of syllabus.

As for the components of teaching- learning programs (Table 2), vast majority of the respondents (82-92\%) found that the number and duration of theory classes, number and duration on clinical sessions to be appropriate. Respondents' opinions on student motivation and support by faculty members (Table 3 ) showed that majority of respondents (87.7\%) agreed on at least one faculty member highly motivated them for pursuing their future aspirations in dentistry and they considered a faculty member whom they considered an ideal dentist. Institutional infrastructure and administrative services (Table 4) data showed a mixture of positive and neutral responses from the participants. Some respondents commented that the administrative officers should be more efficient in handling paperwork. The respondents were ambivalent about their satisfaction with the hostel facilities (50.7\%) and availability of food on campus (45.2\%).

The results depicting confidence level of respondents in 
carrying out common clinical procedures (Table 5) showed a need for further training in some procedures including oral diagnosis, oral radiography, fabrication of fixed prosthesis (crown and bridge), root canal treatment on posterior teeth and basic management of a child patient. Conversely, majority of the respondents are confident in performing restorative care $(80.8 \%)$, followed by basic periodontal care $(79.5 \%)$ and dental extractions $(75.3 \%)$.

The intern's confidence level on practice management and future endeavors were tabulated (Table 6 ). About $56.2 \%$ of the respondents were neutral about setting up a general dental practice; $65.8 \%$ of interns wished to continue further studies and felt confident about future career in dentistry. Besides that, career choice and preferences for postgraduate studies were also presented (Table 7). M ost of the respondents chose their first preference as Conservative Dentistry and Endodontic (31.7\%), followed by Oral Surgery (22.2\%), Pediatric Dentistry (12.7\%) and the specialty that is least preferred is Prosthodontics (14.3\%) followed by Periodontics (11.1\%).The reasons for respondents to continue post-graduation were mainly because of interest and to gain new experience. However, some of the respondents $(11.0 \%)$ were not interested to further their studies due to time needed to complete the course and family commitment. Minority of the respondents commented that they planned to go abroad or work if they are not joining post-graduation.

Regarding the interns' experiences at the rural satellite centers, a vast majority stated that they gained good learning experiences including learning new techniques, better patient exposures resulting in increased selfconfidence and independence. The respondents suggested some improvements required at the rural satellite centers like better materials, improvised instruments, proper sterilization, hostel facilities, and provision of transportation and increase in salary for support staff.

Table 1 : Opinions about the components of learning experience in the undergraduate curriculum, by number and percentage of respondents to each item.

\begin{tabular}{|c|c|c|c|c|c|c|c|c|c|c|c|c|c|c|}
\hline & \multicolumn{2}{|c|}{$\begin{array}{l}\text { Strongly } \\
\text { Agree }\end{array}$} & \multicolumn{2}{|c|}{ Agree } & \multicolumn{2}{|c|}{ Neutral } & \multicolumn{2}{|c|}{ Disagree } & \multicolumn{2}{|c|}{$\begin{array}{l}\text { Strongly } \\
\text { Disagree }\end{array}$} & \multicolumn{2}{|c|}{$\begin{array}{l}\text { Double Entry/ } \\
\text { Not Recorded }\end{array}$} & \multicolumn{2}{|c|}{ Total } \\
\hline $\begin{array}{l}\text { I received adequate } \\
\text { basic sciences training } \\
\text { that prepared me for } \\
\text { clinical practice. }\end{array}$ & 17 & $23.3 \%$ & 47 & $64.4 \%$ & 6 & $8.2 \%$ & 1 & $1.4 \%$ & 0 & $0 \%$ & 2 & $2.8 \%$ & 73 & $100 \%$ \\
\hline $\begin{array}{l}\text { I had adequate clinical } \\
\text { training under } \\
\text { personal supervision } \\
\text { of faculty. }\end{array}$ & 22 & $30.1 \%$ & 34 & $46.6 \%$ & 15 & $20.5 \%$ & 1 & $1.4 \%$ & 0 & $0 \%$ & 1 & $1.4 \%$ & 73 & $100 \%$ \\
\hline $\begin{array}{l}\text { l enjoyed the theory } \\
\text { lectures and the } \\
\text { method of teaching } \\
\text { (overall for all faculty } \\
\text { members) }\end{array}$ & 10 & $13.7 \%$ & 44 & $60.3 \%$ & 17 & $23.3 \%$ & 1 & $1.4 \%$ & 0 & $0 \%$ & 1 & $1.4 \%$ & 73 & $100 \%$ \\
\hline $\begin{array}{l}\text { Internship is a } \\
\text { necessary part of the } \\
\text { BDS curriculum for } \\
\text { consolidating learning. }\end{array}$ & 53 & $72.6 \%$ & 14 & $19.2 \%$ & 3 & $4.1 \%$ & 0 & $0 \%$ & 1 & $1.4 \%$ & 2 & $2.7 \%$ & 73 & $100 \%$ \\
\hline $\begin{array}{l}\text { Internship is an } \\
\text { additional burden } \\
\text { and is not needed. }\end{array}$ & 5 & $6.8 \%$ & 3 & $4.1 \%$ & 3 & $4.1 \%$ & 19 & $26.0 \%$ & 41 & $56.2 \%$ & 2 & $2.7 \%$ & 73 & $100 \%$ \\
\hline $\begin{array}{l}\text { I am satisfied overall } \\
\text { with my BDS training. }\end{array}$ & 23 & $31.5 \%$ & 38 & $52.1 \%$ & 8 & $11.0 \%$ & 3 & $4.1 \%$ & 1 & $1.4 \%$ & 0 & $0 \%$ & 73 & $100 \%$ \\
\hline
\end{tabular}


Table 2 : Opinion about the components of teaching-learning programs, by number and percentage of respondents to each item.

\begin{tabular}{|c|c|c|c|c|c|c|c|c|c|c|}
\hline & \multicolumn{2}{|c|}{ Inadequate } & \multicolumn{2}{|c|}{ Appropriate } & \multicolumn{2}{|c|}{ Excessive } & \multicolumn{2}{|c|}{$\begin{array}{l}\text { Double Entry/ } \\
\text { Not recorded }\end{array}$} & \multicolumn{2}{|c|}{ Total } \\
\hline Number of theory classes & 2 & $2.7 \%$ & 67 & $91.8 \%$ & 4 & $5.5 \%$ & 0 & $0 \%$ & 73 & $100 \%$ \\
\hline Duration of theory classes (1 hour) & 1 & $1.4 \%$ & 60 & $82.2 \%$ & 11 & $15.1 \%$ & 1 & $1.4 \%$ & 73 & $100 \%$ \\
\hline Number of patients to whom I provided treatment & 3 & $4.1 \%$ & 63 & $86.3 \%$ & 6 & $8.2 \%$ & 1 & $1.4 \%$ & 73 & $100 \%$ \\
\hline Number of patients I got to examine & 4 & $5.5 \%$ & 64 & $87.7 \%$ & 5 & $6.8 \%$ & 0 & $0 \%$ & 73 & $100 \%$ \\
\hline Number of clinical sessions & 8 & $11.0 \%$ & 62 & $84.9 \%$ & 3 & $4.1 \%$ & 0 & $0 \%$ & 73 & $100 \%$ \\
\hline Duration of clinical sessions & 5 & $6.8 \%$ & 67 & $91.8 \%$ & 1 & $1.4 \%$ & 0 & $0 \%$ & 73 & $100 \%$ \\
\hline Amount of clinical materials provided & 25 & $34.2 \%$ & 48 & $65.8 \%$ & 0 & $0 \%$ & 0 & $0 \%$ & 73 & $100^{\circ}$ \\
\hline
\end{tabular}

Table 3 : Opinion about support and faculty members, by number and percentage of respondents to each item.

\begin{tabular}{|c|c|c|c|c|c|c|c|c|c|c|c|c|c|c|}
\hline & \multicolumn{2}{|c|}{$\begin{array}{l}\text { Strongly } \\
\text { Agree }\end{array}$} & \multicolumn{2}{|c|}{ Agree } & \multicolumn{2}{|c|}{ Neutral } & \multicolumn{2}{|c|}{ Disagree } & \multicolumn{2}{|c|}{$\begin{array}{l}\text { Strongly } \\
\text { Disagree }\end{array}$} & \multicolumn{2}{|c|}{$\begin{array}{l}\text { Double entry/ } \\
\text { Not recorded }\end{array}$} & \multicolumn{2}{|c|}{ Total } \\
\hline $\begin{array}{l}\text { received adequate } \\
\text { personal counseling } \\
\text { from faculty members } \\
\text { when sought. }\end{array}$ & 15 & $20.5 \%$ & 33 & $45.2 \%$ & 22 & $30.1 \%$ & 3 & $4.1 \%$ & 0 & $0 \%$ & 0 & $0 \%$ & 73 & $100 \%$ \\
\hline $\begin{array}{l}\text { received adequate } \\
\text { encouragement when } \\
\text { my performance was } \\
\text { not up to the mark. }\end{array}$ & 11 & $15.1 \%$ & 43 & $58.9 \%$ & 17 & $23.3 \%$ & 1 & $1.4 \%$ & 0 & $0 \%$ & 1 & $1.4 \%$ & 73 & $100 \%$ \\
\hline $\begin{array}{l}\text { I found here a faculty } \\
\text { member whom I } \\
\text { consider an ideal } \\
\text { dentist. }\end{array}$ & 35 & $47.9 \%$ & 26 & $35.6 \%$ & 12 & $16.4 \%$ & 0 & $0 \%$ & 0 & $0 \%$ & 0 & $0 \%$ & 73 & $100 \%$ \\
\hline $\begin{array}{l}\text { I found here a faculty } \\
\text { member whom I } \\
\text { consider an ideal } \\
\text { teacher. }\end{array}$ & 34 & $46.6 \%$ & 26 & $35.6 \%$ & 9 & $12.3 \%$ & 1 & $1.4 \%$ & 0 & $0 \%$ & 3 & $4.1 \%$ & 73 & $100 \%$ \\
\hline $\begin{array}{l}\text { At least one faculty } \\
\text { member highly } \\
\text { motivated me for } \\
\text { pursuing my future } \\
\text { aspirations in dentistry. }\end{array}$ & 38 & $52.1 \%$ & 26 & $35.6 \%$ & 7 & $9.6 \%$ & 0 & $0 \%$ & 0 & $0 \%$ & 2 & $2.7 \%$ & 73 & $100 \%$ \\
\hline
\end{tabular}

Table 4 : Opinion regarding infrastructure and administrative services, by number and percentage of respondents to each item.

\begin{tabular}{|l|c|c|c|c|c|c|c|c|c|c|c|c|c|c|}
\hline & \multicolumn{2}{|c|}{$\begin{array}{c}\text { Strongly } \\
\text { Agree }\end{array}$} & \multicolumn{2}{|c|}{ Agree } & \multicolumn{2}{|c|}{ Neutral } & \multicolumn{2}{|c|}{ Disagree } & \multicolumn{2}{|c|}{$\begin{array}{l}\text { Strongly } \\
\text { Disagree }\end{array}$} & $\begin{array}{l}\text { Double entry/ } \\
\text { Not recorded }\end{array}$ & \multicolumn{3}{|c|}{ Total } \\
\hline $\begin{array}{l}\text { I was satisfied with } \\
\text { the college library. }\end{array}$ & 11 & $15.1 \%$ & 32 & $43.8 \%$ & 23 & $31.5 \%$ & 5 & $6.8 \%$ & 0 & $0 \%$ & 2 & $2.7 \%$ & 73 & $100 \%$ \\
\hline $\begin{array}{l}\text { I received adequate } \\
\text { support and help } \\
\text { from the } \\
\text { administrative office. }\end{array}$ & 5 & $6.8 \%$ & 28 & $39.7 \%$ & 26 & $35.6 \%$ & 8 & $11.0 \%$ & 4 & $5.5 \%$ & 1 & $1.4 \%$ & 73 & $100 \%$ \\
\hline $\begin{array}{l}\text { I received adequate } \\
\text { support and help from } \\
\text { the non teaching } \\
\text { faculty. }\end{array}$ & 8 & $11.0 \%$ & 28 & $38.4 \%$ & 26 & $35.6 \%$ & 8 & $11.0 \%$ & 2 & $2.7 \%$ & 1 & $1.4 \%$ & 73 & $100 \%$ \\
\hline $\begin{array}{l}\text { I was satisfied with the } \\
\text { facilities in the hostel. } \\
\text { I was satisfied with the } \\
\text { availability of food on } \\
\text { campus (mess \& others). }\end{array}$ & 6 & $8.2 \%$ & 27 & $37.0 \%$ & 24 & $32.9 \%$ & 10 & $13.7 \%$ & 2 & $2.7 \%$ & 4 & $5.4 \%$ & 73 & $100 \%$ \\
\hline
\end{tabular}


Table 5 : Confidence in carrying out specific clinical procedures, by number and percentage of respondents to each item.

\begin{tabular}{|c|c|c|c|c|c|c|c|c|c|c|}
\hline & \multicolumn{2}{|c|}{ Confident } & \multicolumn{2}{|c|}{ Neutral } & \multicolumn{2}{|c|}{ Not Confident } & \multicolumn{2}{|c|}{$\begin{array}{l}\text { Double Entry/ } \\
\text { Not recorded }\end{array}$} & \multicolumn{2}{|c|}{ Total } \\
\hline Dental extractions & 55 & $75.3 \%$ & 16 & $21.9 \%$ & 0 & $0 \%$ & 2 & $2.8 \%$ & 73 & $100 \%$ \\
\hline Restorative care & 59 & $80.8 \%$ & 13 & $17.8 \%$ & 0 & $0 \%$ & 1 & $1.4 \%$ & 73 & $100 \%$ \\
\hline Oral diagnosis & 32 & $43.8 \%$ & 38 & $52.1 \%$ & 2 & $2.7 \%$ & 1 & $1.4 \%$ & 73 & $100 \%$ \\
\hline Oral radiography & 29 & $39.7 \%$ & 37 & $50.7 \%$ & 5 & $6.8 \%$ & 2 & $2.7 \%$ & 73 & $100 \%$ \\
\hline Basic periodontal care & 58 & $79.5 \%$ & 13 & $17.8 \%$ & 1 & $1.4 \%$ & 1 & $1.4 \%$ & 73 & $100 \%$ \\
\hline Fabrication of removable partial denture (acrylic) & 49 & $67.1 \%$ & 21 & $28.8 \%$ & 2 & $2.7 \%$ & 1 & $1.4 \%$ & 73 & $100 \%$ \\
\hline Fabrication of removable complete denture (acrylic) & 48 & $65.8 \%$ & 23 & $31.5 \%$ & 1 & $1.4 \%$ & 1 & $1.4 \%$ & 73 & $100 \%$ \\
\hline Fabrication of single unit fixed prosthesis (crown) & 22 & $30.1 \%$ & 19 & $26.0 \%$ & 29 & $39.7 \%$ & 3 & $4.1 \%$ & 73 & $100 \%$ \\
\hline Fabrication of multiple unit fixed prosthesis (bridge) & 11 & $15.1 \%$ & 18 & $24.7 \%$ & 42 & $57.5 \%$ & 2 & $2.7 \%$ & 73 & $100 \%$ \\
\hline Root canal treatment of anterior teeth & 40 & $54.8 \%$ & 18 & $24.7 \%$ & 15 & $20.5 \%$ & 0 & $0 \%$ & 73 & $100 \%$ \\
\hline Root canal treatment of posterior teeth & 14 & $19.2 \%$ & 26 & $35.6 \%$ & 33 & $45.2 \%$ & 0 & $0 \%$ & 73 & $100 \%$ \\
\hline Basic management of a child patient & 23 & $31.5 \%$ & 39 & $53.4 \%$ & 11 & $15.1 \%$ & 0 & $0 \%$ & 73 & $100 \%$ \\
\hline Educating a patient for good oral health & 48 & $65.8 \%$ & 23 & $31.5 \%$ & 2 & $2.7 \%$ & 0 & $0 \%$ & 73 & $100 \%$ \\
\hline Method of taking informed consent & 37 & $50.7 \%$ & 29 & $39.7 \%$ & 7 & $9.6 \%$ & 0 & $0 \%$ & 73 & $100 \%$ \\
\hline Counseling a patient for discontinuation of tobacco use & 34 & $46.6 \%$ & 29 & $39.7 \%$ & 10 & $13.7 \%$ & 0 & $0 \%$ & 73 & $100 \%$ \\
\hline
\end{tabular}

Table 6 : Confidence about practice management and other future endeavors, by number and percentage of respondents to each item.

\begin{tabular}{|c|c|c|c|c|c|c|c|c|c|c|}
\hline & \multicolumn{2}{|c|}{ Confident } & \multicolumn{2}{|c|}{ Neutral } & \multicolumn{2}{|c|}{ Not Confident } & \multicolumn{2}{|c|}{$\begin{array}{l}\text { Double Entry/ } \\
\text { Not recorded }\end{array}$} & \multicolumn{2}{|c|}{ Total } \\
\hline Dental extractions & 55 & $75.3 \%$ & 16 & $21.9 \%$ & 0 & $0 \%$ & 2 & $2.8 \%$ & 73 & $100 \%$ \\
\hline I am confident to set up a general dental practice. & 19 & $26.0 \%$ & 41 & $56.2 \%$ & 13 & $17.8 \%$ & 0 & $0 \%$ & 73 & $100 \%$ \\
\hline I wish to take a course on general dentistry. & 40 & $54.8 \%$ & 29 & $39.7 \%$ & 3 & $4.1 \%$ & 1 & $1.4 \%$ & 73 & $100 \%$ \\
\hline I wish to take a course on orientation to post graduation. & 48 & $65.8 \%$ & 24 & $32.9 \%$ & 1 & $1.4 \%$ & 0 & $0 \%$ & 73 & $100 \%$ \\
\hline I feel confident about my future career in dentistry. & 48 & $65.8 \%$ & 22 & $30.1 \%$ & 2 & $2.7 \%$ & 1 & $1.4 \%$ & 73 & $100 \%$ \\
\hline I feel apprehensive about my future career in dentistry. & 27 & $37 \%$ & 32 & $43.8 \%$ & 11 & $15.1 \%$ & 3 & $4.1 \%$ & 73 & $100 \%$ \\
\hline
\end{tabular}

Table 7 : Career choice and preferences for specialties, by number and percentage of total respondents.

\begin{tabular}{|l|c|c|c|c|c|c|c|c|}
\hline Specialty & \multicolumn{2}{|c|}{ First Preference } & \multicolumn{2}{|c|}{ Second Preference } & \multicolumn{2}{|c|}{ Third Preference } & \multicolumn{2}{|c|}{ Least Preferred } \\
\hline Public Health Dentistry & 1 & $1.6 \%$ & 1 & $1.6 \%$ & 2 & $3.2 \%$ & 1 & $1.6 \%$ \\
\hline Pediatric Dentistry & 8 & $12.7 \%$ & 12 & $19.0 \%$ & 11 & $17.5 \%$ & 4 & $6.3 \%$ \\
\hline Periodontics & 1 & $1.6 \%$ & 6 & $9.5 \%$ & 2 & $3.2 \%$ & 7 & $11.1 \%$ \\
\hline Prosthodontics & 5 & $7.9 \%$ & 7 & $11.1 \%$ & 6 & $9.5 \%$ & 9 & $14.3 \%$ \\
\hline Oral M edicine and Radiology & 2 & $3.2 \%$ & 0 & $0 \%$ & 7 & $11.1 \%$ & 5 & $7.9 \%$ \\
\hline Conservative Dentistry and Endodontics & 20 & $31.7 \%$ & 16 & $25.4 \%$ & 9 & $14.3 \%$ & 3 & $4.8 \%$ \\
\hline Orthodontics & 7 & $11.1 \%$ & 12 & $19 \%$ & 5 & $7.5 \%$ & 6 & $9.5 \%$ \\
\hline Oral Pathology & 0 & $0 \%$ & 2 & $3.2 \%$ & 0 & $0 \%$ & 4 & $6.3 \%$ \\
\hline Oral Surgery & 14 & $22.2 \%$ & 2 & $3.2 \%$ & 11 & $17.5 \%$ & 6 & $9.5 \%$ \\
\hline Forensic Dentistry & 1 & $1.6 \%$ & 0 & $0 \%$ & 0 & $0 \%$ & 1 & $1.6 \%$ \\
\hline None & 4 & $6.3 \%$ & 5 & $7.9 \%$ & 9 & $14.3 \%$ & 16 & $25.4 \%$ \\
\hline Double Entry & 0 & $0 \%$ & 0 & $0 \%$ & 1 & $1.6 \%$ & 1 & $1.6 \%$ \\
\hline Total & 63 & $100 \%$ & 63 & $100 \%$ & 63 & $100 \%$ & 63 & $100 \%$ \\
\hline
\end{tabular}

* Seventy one interns responded to the questions about whether they wanted to pursue postgraduate study: sixty three (86.3\%) wanted to and eight (11.0\%) did not. Percentages may not total 100\% because of rounding.

\section{Discussion}

Students are the end users or beneficiaries of the educational program. Obtaining opinions from the students who are completing their course about their perception and experiences about curriculum, teaching- learning programs, student motivation and support system is very important. Their perspective on the student motivation and support system, institutional infrastructure, administrative services, confidence in carrying out common clinical procedures and confidence in 
practice management area is also very important. In this study, we would like to answer these aspects about present BDScurriculum in our institution.

In the present study, majority of the respondents showed an overall satisfaction with their BDStraining. However, the students suggested that certain dental procedures such as root canal procedure should be allowed to be done on patients at undergraduate level for better experience and confidence. Most of the respondents agreed that the internship is needed as this gives them more exposure in clinical procedures and patient management, which increases their self-confidence to practice dentistry independently. The Dental Council of India regulations for the BDS curriculum suggests $4+1$ years of undergraduate training with a one year compulsory internship program ${ }^{1}$ as compared to School Of Dentistry and Oral Health, Griffith University, Australia, in which their residency program only involves twenty-one weeks. The graduates of Griffith University, Australia felt that their training duration was inadequate which is in contrast to the present study. ${ }^{13}$

On the aspect of teaching-learning program, majority of the respondents felt the duration of theory class is appropriate; however, minority of the respondents (15.1\%) preferred that the duration of each theory class should be less than 1 hour as this will be able to keep them concentrated during the lecture. In a similar study conducted in Maharashtra, India ${ }^{8}$, majority of the respondents favored a shorter duration of theory classes and suggested forty-five minutes duration over the existing one hour lecture. This change is advisable and corresponds to the opinions of the education experts who report that after about 20 minutes of lecture there is a sharp decline in attention level of the students. The cognitive load theory proposes a break in the lecture with some form of student activity to regain the attention ${ }^{14,15}$. The curriculum experts need to pay attention to this fact and design the classroom teaching hours according to the capacity of the human mind to pay attention!

The students preferred interactive lectures with distribution of lecture notes prior to the conduction of class, so that the students can have a general idea, hence, better interaction and understanding. This is also reported by other surveys where students valued interactive teaching over conventional lecturing ${ }^{16}$. Improving the teacher's sensitivity to the needs of active learning and introduction of activities could improve active engagement of the learners in the subject of study ${ }^{17}$. There are now excellent guidelines available in this regard and universities and institutions should actively adapt this into the current curriculum ${ }^{18}$.

In terms of clinical training, most of the respondents agreed that they have been exposed to an adequate amount of patients and they are satisfied with the clinical exposure given, such as live demonstrations and excellent guidance by the staff. However, they prefer that the quality of treatment should be considered more than the number of patients; hence, a reduction in quota is recommended. Demonstrations on recent advances in dentistry should be provided as well. Providing patients for university exam is highly suggested by the respondents so that they can focus more on exam preparation.

Some respondents find certain faculty as their role model and feel motivated by them. A good teaching staff-student relationship can be observed which gives a harmony in learning environment. A good interpersonal relation is also highly valued by students as reported by earlier reports ${ }^{19}$.

M any rooms of improvements were suggested in terms of college infrastructure and administrative services. Improvement with respect to certain infrastructure such as centralized AC in college with WIFI connection, and uninterrupted supply of materials, better equipment are highly recommended by the respondents for efficient and effective quality treatment. Also, provision of prayer room within the common room was proposed by a student. Increase of efficiency of the administrative office was sought by students to reduce delay in processing documents. Interns also opined against monetary fine as a mode of punishment for indiscipline. It is necessary to keep upgrading the infrastructure and student support services as a continuous process to keep up with the demands of 
international standards. Though the student learning is most important component of a dental school it should also be noted that international rating of an educational institution increasingly requires high quality infrastructure.

Majority of the respondents are confident in carrying out most of the common clinical procedures at the undergraduate level. However, they lack confidence in performing certain procedures such as root canal treatment especially for posterior teeth and fabrication of fixed prosthesis. Half of the number of interns remained 'neutral' about their ability in carrying out in oral diagnosis, oral radiography and basic management of child patient, compared to University of $\mathrm{Manitoba}^{20}$, where the confidence level in oral radiography is higher. Thus, clinical training may concentrate more on clinically relevant competencies.

Majority of the respondents wished to pursue postgraduation, in which the highest first preference was for Conservative Dentistry and Endodontics, followed by Oral and Maxillofacial Surgery, Pediatric Dentistry, Orthodontics, Prosthodontics, Oral Medicine and Radiology, Public Health Dentistry, Periodontics, Forensic Dentistry and the least preferred is Oral Pathology. The reason for such preference is mostly due to personal interest. A minority of the respondents were not interested to further their studies due to several reasons; work, going abroad, marriage etc. In dental school of Capital Medical University, China ${ }^{21}$, only half of the graduating dental students planned to pursue postgraduate education as they were more interested in general clinical practice.

A considerable number of respondents were not confident about setting up a general dental practice. In contrast, a study conducted in Australia ${ }^{13}$ showed majority of the graduating dental students had confidence in establishing an independent practice after graduation. This highlights the need for a 'competency based' system to be incorporated into Indian dental curriculum. A number of western countries have defined a competency based curriculum where an assessment is carried out to evaluate the competency of the general dental practitioners. For example; it is compulsory for general dental practitioners in United Kingdom to appear and qualify diploma and membership examinations established by colleges in United Kingdom ${ }^{19}$. Problem Based Learning (PBL) could be implemented in Indian dental curriculum to increase the confidence of students and dental graduates. .

A.B. Shetty M emorial Institute of Dental Sciences runs 15 rural dental satellite centers which are about $100-150 \mathrm{~km}$ from the dental college, located in the districts of Dakshina Kannada, Udupi, Chikmagalur (Karnataka State) and Kasargod district of Kerala. There is a compulsory 3 months rural posting at any of these 15 rural dental satellite centers during the internship period. The interns claimed that they have gained a whole lot of new experience regarding new clinical procedures, improving their self-confidence and patient management in the rural areas. However, there are a few challenges like transportation to rural area, language barrier, accommodation, better instruments and equipments.

Even though the study received a high number of participants, there are some fallbacks in the study, such as unable to gain hundred-percent feed back from the interns. There are errors in answering the questionnaire as there are double entries and/or blank answers on certain items in the questionnaire. This somehow affects the data analysis but not the validity of the whole study.

\section{Conclusion}

In a nutshell, the study successfully identified the assets and liabilities of the present BDS curriculum ${ }^{1}$. Some of the strengths are; excellent learning experience and internship program, satisfactory teaching learning program, good student motivation and support. M ean while, weaknesses that can be observed are; inadequate clinical trainings and hands on dental practice in terms of quality. 


\section{References}

1. Dental council of India, Implementation of DCI Revised 80SCourse (3rd Amendment), 2011. Available at: http://www.dciindia.org /annoncment_pdf_files/pdf_files/B-2211\%20Implementation $\% 20$ of\%20DCl\%20revised\%20B.D.S.\%20Course.pdf (Accessed on: 28.08.2014)

2. Al-Naggar RA, Abdulghani M, Osman MT, Al-Kubaisy W, Daher AM, Nor Aripin KN, Assabri A, Al-Hidabi DA, Ibrahim MI, Al-Rofaai A, Ibrahim HS, Al-Talib H, Al-Khateeb A, Othman GQ, Abdulaziz QA, Chinna K, Bobryshev YV. The Malaysia DREEM : perceptions of medical students about the learning environment in a medical school in Malaysia. Adv Med Educ Pract. 2014 Jun 9;5:177-84.

3. Ostapczuk M S, Hugger A, de Bruin J, Ritz-Timme S, Rotthoff T. DREEM on, dentists! Students' perceptions of the educational environment in a German dental school as measured by the Dundee Ready Education Environment M easure. EurJ Dent Educ. 2012 M ay;16(2):67-77.

4. Kang I, Foster Page LA, Anderson VR, Thomson WM, Broadbent JM. Changes in students' perceptions of their dental education environment. Eur J Dent Educ. 2014 Jul 17. doi: 10.1111/eje.12112. [Epub ahead of print]

5. Kohli V, Dhaliwal U. Medical students' perception of the educational environment in a medical college in India: a cross-sectional study using the Dundee Ready Education Environment questionnaire. J Educ Eval Health Prof. 2013Jun 30;10:5.

6. Jawaid M, Raheel S, Ahmed F, Aijaz H. Students' perception of educational environment at Public Sector Medical University of Pakistan. J Res M ed Sci. 2013 M ay;18(5):417-21.

7. Shankar PR, Dubey AK, Balasubramanium R. Students' perception of the learning environment at Xavier University School of Medicine, Aruba.J Educ Eval Health Prof. 2013 Sep 30;10:8.

8. Shetty VB, Shirahatti RV, Pawar P. Students' perceptions of their education on graduation from a dental school in India. J Dent Educ. 2012 Nov; 76(11):1520-6.

9. Lockwood JH, Danoff D, Whitcomb ME. The AAM C's 2000 graduation questionnaire. Association of American M edical Colleges. JAM A. 2000 Sep 6; 284(9):1080.

10. Roff S. The Dundee Ready Educational Environment Measure
(DREEM )--a generic instrument for measuring students' perceptions of undergraduate health professions curricula. Med Teach. 2005 Jun;27(4):322-5

11. M iles S, Swift L, Leinster S). The Dundee Ready Education Environment Measure (DREEM): a review of its adoption and use. Med Teach. 2012;34(9):e620-34.

12. Burnard P, Gill P, Stewart K, Treasure E, Chadwick B. Analysing and presenting qualitative data. Br Dent J . 2008 Apr 26;204(8):429-32.

13. Manakil J, George R. Self-perceived work preparedness of the graduating dental students. Eur J Dent Educ. 2013 M ay;17(2):101-5.

14. Young, J. Q., Van Merrienboer, J., Durning, S., \& Ten Cate, O. (2014). Cognitive Load Theory: implications for medical education: AMEE Guide No. 86. Medical teacher, 36(5), 371-384.

15. Kaufman, D.M., \& Mann, K.V. (2010). Teaching and learning in medical education: how theory can inform practice. In: Swanwick, T. (Eds). Understanding Medical Education: Evidence, Theory and Practice, Wiley-Blackwell.

16. Pettit, J.E., Axelson, R.D., Ferguson, K.J., Rosenbaum, M.E. (2014). Assessing Effective Teaching: What Medical Students Value When Developing Evaluation Instruments. Academic M edicine. Aug 5. [Epub ahead of print]

17. Brown, G., \& M anogue, M. (2001). AM EE M edical Education Guide No. 22: Refreshing lecturing: a guide for lecturers. M edical teacher, 23(3), 231-244.

18. Gibbs, T. (2007). Advancing medical education: the new series of AM EE guides in medical education. M edical teacher, 29 (6): 525-6.

19. Schönwetter DJ, Law D, Mazurat R, Sileikyte R, Nazarko O. Assessing graduating dental students' competencies: the impact of classroom, clinic and externships learning experiences. Eur J Dent Educ. 2011 Aug;15(3):142-52.

20. Zhao L, Sun C, Lv H, Sun Z. Practice plans of and factors influencing graduating dental students in China. Int Dent J. 2014 May 26. doi: 10.1111/idj.12112. [Epub ahead of print]

21. Yip HK, Smales RJ. Review of competency based education in dentistry. Br Dent J. 2000; 189 (6): 324-26. 